\title{
ЭКОЛОГИЧЕСКИ ПРИЕМЛЕМАЯ ТЕХНОЛОГИЯ ПОЛУЧЕНИЯ ФОСФОРСОДЕРЖАЩИХ ОРГАНОМИНЕРАЛЬНЫХ УДОБРЕНИЙ НА ОСНОВЕ ОТХОДОВ ЖИВОТНОВОДСТВА И НЕКОНДИЦИОННЫХ ФОСФОРИТОВ
}

\author{
У.Ш. Темиров ${ }^{1}$, Ш. С. Намазов ${ }^{2}$, Н.Х. Усанбаев ${ }^{2}$, Д.А. Азимова ${ }^{2}$ Х. М. Каноатов ${ }^{3}$ \\ ${ }^{1}$ Кафедра Химическая технология, Навоийский государственный горный институт, Узбекистан, \\ Навоийская область г. Навои ул. Жанубий, 27-а, 210100. E-mail: temirov-2012@mail.ru. \\ 2 Лаборатория Фосфорных удобрений, Институт общей и неорганической химии Академии наук Республика \\ Узбекистан, Узбекистан, Ташкент, ул. Мирзо Улугбек, 77-a, 100170.E-mail: najim70@mail.ru.
}

${ }^{3}$ Наманганский инженерно-технологический институт, Узбекистан, Наманганская область г. Наманган ул. Касансай 7. 160115.E-mail: kanoatov8086@mail.ru.

В статье приведены результаты изучения процессов получения органоминеральных удобрений путем колпостирования навоза крупного рогатого скота (КРC) с добавкой активизированного фосфорита (АФ) азотной кислотой в зависимости от нормы азотной кислоть, продолжительности компостирования, весовых соотношений исходных компонентов и влажности компостируемой массы. Изучена зависимость эффективности добавки АФ азотной кислотой при нормах 20-60\% от стехиометрии на СаО содержащеегося в фосфатном сырье и компостировании в течение трех месяцев в интервале весовых соотношений навоз КРС : АФ = 100 :(2-25). Показано что, АФ азотной кислотой обладает наиболее лучшими свойствами для снижения выделения вредных газов на окружаюшую среду, на увеличение гумификаџии органических веществ компостов, приготовленных на основе навоза КРС. Найдено, что предварительная разложения фосфатного сырья азотной кислотой при норме $40 \%$ от стехиометрии на разложение СаО содержащеегося в фосфатном сырье в течение 30 минут и добавка его к навозу КРС перед компостированием при весовых соотношениях навоз КРС :АФ = 100:20 и выдерживание в течение трех месяиев при влажности 65-75\% позволяет увеличить степень превращения органической части навоза в гумусовые вещества от 41,64 до 60,42 \%, снижению потери азота и органических вещееств от 28,67 до 5,5\% и от 23,54 до 8,19\% соответственно. Кроме этого за счет увеличение оброзавания гуминовых веществ увеличивается относительное содержание $P_{2} O_{5}$ усв. по трилону Б от 32,19 до 77,38\%. Снижения потери азота и органических веществ объясняется тем что АФ азотной кислотой содержит в своем составе водорастворимый кальцчий нитрат, монокальцийфосфат и усвояемый дикальцийфосфат, кроме этого рН среда также снижается и при добавке его к навозу КРС перед компостированием в компостах создаётся более оптимальное условие для взаимодействия органических кислот, аммиака с ионами кальция и нитрата и образованию качественного органоминерального удобрения с минимальным выделением в окружающую среду вредных газов что является предпосылкой для получения экологически безопасной фосфорсодержаичих органоминеральных удобрений.

Ключевые слова. Навоз, азотная кислота, активизированный фосфорит, фосфор, гуминовые кислоты, фульвокислоты, компост, органические кислоты, экология, окружающая среда. 


\title{
ECOLOGICALLY APPROPRIATE TECHNOLOGY FOR OBTAINING PHOSPHOROSE-CONTAINING ORGANOMINERAL FERTILIZERS BASED ON LIVESTOCK WASTE AND LOW GRADE PHOSPHORITES
}

\author{
U.Sh. Temirov ${ }^{1}$, Sh.S. Namazov ${ }^{2}$, N. Kh. Usanbayev', D.A. Azimova ${ }^{2}$, Kh. M. Kanoatov ${ }^{3}$ \\ ${ }^{1}$ Department of Chemical Technology Navoi State Mining Institute, Uzbekistan, Navoi region, Navoi St. Janubiy, \\ 27-a,210100.E-mail: temirov-2012@mail.ru. \\ ${ }^{2}$ Laboratory of Phosphate fertilizer, Institute of general and inorganic chemistry of Uzbek Academy of Sciences, \\ Uzbekistan,Tashkent, Mirzo Ulugbek St., 77-a,100170.E-mail:najim70@mail.ru.
}

${ }^{3}$ Namangan institute of engineering and technologi. Uzbekistan, Namangan region, Namangan sity, st.Kasansai 7. 160115.E-mail: kanoatov8086@mail.ru.

The results of studying the processes of obtaining organomineral fertilizers by composting cattle manure (cattle) with the addition of activated phosphorite (AP) with nitric acid, depending on the rate of nitric acid, the residence time of composting, the weight ratios of the initial components and the moisture content of the compost mass are given in this article. The dependence of the effectiveness of the addition of AP with nitric acid at rates of 20-60\% over the stoichiometry for CaO contained in the phosphate raw material and composting for three months in the range of weight ratios of cattle manure: AP =100: (2-25) was studied. It is shown that AP with nitric acid has the best properties for reducing the emission of harmful gases to the environment, for increasing the humification of organic matter in composts prepared based on cattle manure. It was found that preliminary decomposition of phosphate raw materials with nitric acid at a rate of $40 \%$ of stoichiometry over decomposition of $\mathrm{CaO}$ contained in phosphate raw materials for 30 minutes and its addition to cattle manure before composting at weight ratios of cattle manure: AP $=100: 20$. At that, aging for three months with a humidity of $65-75 \%$ allows to increase the degree of conversion of the organic part of manure into humic substances from 41,64 to 60,42\%, reducing the loss of nitrogen and organic matter from 28,67 to 5,5\% and from 23,54 to 8,19\% respectively. In addition, due to the increase in the formation of humic substances, the relative content of $\mathrm{P}_{2} \mathrm{O}_{5}$ assimilate on Trilon $B$ increases in a range from 32,19 to 77,38\%. The decrease in the loss of nitrogen and organic matter is explained by the fact that AP with nitric acid contains in its composition water-soluble calcium nitrate, monocalcium phosphate and assimilable dicalcium phosphate. Additionally the $\mathrm{pH}$ of the medium also decreases and when it is added to cattle manure before composting in composts. There has created a more optimal condition for the interaction of organic acids, ammonia with calcium and nitrate ions and the formation of high-quality organomineral fertilizers with minimal release of harmful gases into the environment, which is a prerequisite for obtaining environmentally friendly phosphorus-containing organomineral fertilizers.

Keywords. Manure, nitric acid, activated phosphorite, phosphorus, humic acids, fulvic acids, compost, organic acids, ecology, environment.

\section{Introduction}

At present, the need for agriculture in the Republic of Uzbekistan for phosphorus fertilizers is provided by less than $20-25 \%$. The reason for this is the lack of high-quality phosphate raw materials. In Uzbekistan, the raw materials for the production of phosphorus fertilizers are the phosphorites of the Central Ky- zyl Kum. According to the content of the main component, phosphorus, these phosphorites are classified as poor raw materials. Due to their low phosphorus content, they are unsuitable for the production of traditional phosphorous fertilizers. Therefore, at the Kyzylkum phosphorite complex, a multistage enrichment of phosphorites from the Kyzylkum deposit is being carried out. During enrichment, large losses of phosphorus 
occur. The gross yield of $\mathrm{P}_{2} \mathrm{O}_{5}$ in phosphoconcentrate is only $58 \%$. During dry sorting of ore, off-balance ore, the so-called mineralized mass (MM) $\left(10-14 \% \mathrm{P}_{2} \mathrm{O}_{5}\right)$, is removed from the beneficiation process to the dump. And when washing phosphorite flour (PF) from chlorine, sludge phosphorite (SP) with a content of 10-12\% $\mathrm{P}_{2} \mathrm{O}_{5}$ is formed, which is also thrown into the sludge storage. A pulverized fraction $\left(18-20 \% \mathrm{P}_{2} \mathrm{O}_{5}\right)$ is released at the firing stage of washed dried phosphorite concentrate. In general, 100,94 thousand tons of $\mathrm{P}_{2} \mathrm{O}_{5}$ are lost with them annually. To date, more than 15 million tons of substandard phosphorites have already been accumulated. Laboratory studies have been carried out on phosphoric acid processing of low-grade Kyzylkum phosphorites in order to obtain ammophosphate and double superphosphate $[1,2]$. But this requires phosphoric acid from the production of ammophos and this limits the expansion of the range of phosphorus fertilizers

It should also be noted that there is an acute shortage of organic and organomineral fertilizers in the agriculture of the Republic of Uzbekistan.

At the same time, due to improper storage and lack of rational technologies for processing animal and poultry waste, cattle manure and bird droppings emit harmful substances $\mathrm{CO}_{2}, \mathrm{CH}_{4}, \mathrm{~N}_{2} \mathrm{O}$ and $\mathrm{NH}_{3}$ into the atmosphere. Today, in Uzbekistan, the total number of cattle has reached 12,7 million, and poultry - 75 million. The mass of the resulting manure and poultry droppings per day reaches $6-8 \%$ of the mass of the animal. In total, 110 thousand tons of manure and dung are produced every day. For the year, the total volume is more than 40 million tons. Cattle manure and poultry manure are the most important raw materials for the production of organic and organomineral fertilizers. At present, in the country, cattle manure is partially composted with aging for several months and is used in agriculture. In many farms, manure and poultry droppings are stored, and the accumulated organic waste is used as organic fertilizer. In this case, the humification process does not occur completely, pathogenic microorganisms persist and become a source of soil, water and air pollution. In [3], a quantitative assessment of the impact of technological processes (methods of accumulation and removal of manure from premises, its processing by composting or anaerobic digestion, storage using various types of coatings, the use of inhibiting additives) on the emission of methane, nitrous oxide and ammonia is given. The limits of changes in nitrous oxide emission, depending on the applied technology of keeping animals, are established, constituting $0,002-0,14 \mathrm{~kg} / \mathrm{kg}$ of released nitrogen. The range of methane emissions for different storage systems for cow manure was 5,1-43,4 $\mathrm{kg}$ per livestock place per year. When liquid manure is stored in open storage fa- cilities, the loss of nitrogen in the form of ammonia reaches $15 \%$ of the ammonia nitrogen content. One poultry farm with a capacity of 400 thousand chickens per year produces such an amount of poultry manure that in the process of its decomposition, almost 700 tons of biological gas are released into the atmosphere, of which 450 tons is methane (65 percent), 208 tons is carbon dioxide ( 30 percent), 35 tons of hydrogen sulfide, skatole, ammonia, indole, hydrogen and other compounds (5 percent). Livestock production accounts for $9 \%$ of global carbon dioxide emissions, $65 \%$ of nitrous oxide, $37 \%$ of anthropogenic methane, and $64 \%$ of ammonia. The emission of all these stated above is significantly influenced by the systems for manure removal from premises, storage and production of organic fertilizers on its basis [3-8].

The release of these substances occurs due to the decomposition of the waste contained - urea, hippuric acid, uric acid and other organic substances. At the same time, these substances can be used for binding calcium of substandard phosphorites and converting tricalcium phosphate into dicalcium phosphate, which is easily digested by plants, i.e. for obtaining organomineral fertilizers.

The most rational way to use substandard phosphorites and animal waste, as well as to reduce the emission of harmful gases into the atmosphere, is to compost them in the form of a manure-phosphorite mixture. Composting waste can significantly reduce the environmental problems associated with the accumulation of waste by turning it into a safe valuable product, which is later used as an organic or organomineral fertilizer in agriculture [8].

The composting process has a natural origin and consists in the decomposition of the organic substance of the compost mixture by special groups of aerobic microorganisms. Therefore, to effectively perform the composting process, it is necessary to create optimal conditions for the life and active growth of these microorganisms. The following factors influence the composting process: the ratio of carbon and nitrogen $(\mathrm{C}: \mathrm{N})$ in the compost mixture, its moisture content, $\mathrm{pH}$ value, particle size distribution, uniformity of mixing, ensuring self-isolation in the volume of the compost mixture and its temperature. However, traditional composting methods result in a loss of about $55 \%$ organic matter and 30-50\% nitrogen [9-11].

To obtain a better and more efficient organomineral fertilizer and to create a favorable environment for the composting process, various additives are used (phosphate rock, simple superphosphate, ammonium sulfate, ammonium nitrate, potassium chloride), industrial waste (phosphogypsum) and agricultural ores (bentonite, glauconite, lime and etc.). Compost [12-14] based on animal waste containing inorganic fertilizers 
or the combined use of organic and inorganic fertilizers to improve soil fertility and productivity and to reduce negative environmental impacts during intensive farming have been widely recognized in world agricultural practice.

Based on the above, a number of studies have been conducted to obtain organomineral fertilizers by composting cattle manure with the addition of substandard phosphorites of Central Kyzyl Kum. As a result of research, it has been shown that the preparation of composts based on cattle manure with the addition of phosphate raw materials leads, on the one hand, to an increase in the assimilable form of $\mathrm{P}_{2} \mathrm{O}_{5}$ due to the interaction of humic acids, fulvic acids and water-soluble organic substances with phosphates, on the other hand, to a decrease in the loss of nitrogen and organic substances. At the same time, the assimilable form of $\mathrm{P}_{2} \mathrm{O}_{5}$ of phosphate raw materials increases 6,5-7,0 times, losses of nitrogen and organic matter decrease almost 2,5-3 times, and the degree of humification of organic substances increases 2 times [15-18]. It was also [19] studied the production of organomineral fertilizers by acidifying poultry manure with nitric acid followed by the decomposition of low-grade phosphorites with bird droppings pre-acidified nitric acid. It was shown that when processing the low-grade phosphorites with acidified poultry manure the assimilable form of phosphorus contained in phosphorite, is increased. In addition, the acidification of bird droppings with nitric acid leads to a sharp decrease in the release of nitrogen-containing and various volatile organic substances into the gas phase, which negatively affect the environment.

On the basis of the research carried out for clusters, farms were offered the rate, stages and conditions for the preparation of phosphorite-containing composts. Optimal composting mode: ratio Manure (cattle): substandard phosphorite $=100: 10$, humidity 60-75\%, composting time -3 months. It is recommended to prepare composts in trenches. Compost trenches are prepared as follows. The place allocated for composting is preliminarily deepened with the help of special equipment to $50-70 \mathrm{~cm}, 2,5 \mathrm{~m}$ wide and $30 \mathrm{~m}$ long. Manure is loaded onto the prepared trenches using special equipment, then it is leveled with a thickness of about $20 \mathrm{~cm}$. Phosphate raw materials are scattered on its surface, based on the calculation of $100 \mathrm{~kg}$ per 1 ton of cattle manure. In this sequence, the height of the mixture is brought to $1,5 \mathrm{~m}$. The moisture content of the compost is brought to $65-75 \%$. The top of the compost is covered with a layer of soil $15 \mathrm{~cm}$ thick. In areas where there is groundwater, composts are recommended to be prepared in stacks $1,5-2,0 \mathrm{~m}$ high, $2-2,5 \mathrm{~m}$ wide. The activity of the bio-thermal composting process is largely dependent on humidi- ty, since the microorganisms involved in this process mainly feed in the form of aqueous solutions. Insufficient humidity deprives them of water necessary for metabolism, and leads to a slowdown in the process. Excess moisture fills the voids between the compost particles displacing the air, as a result of which an anaerobic condition is created due to the lack of oxygen, the composting process is sharply inhibited. Therefore, every month the soil is separated from the top of the compost, then the compost is shoveled using a bucket of special equipment, while simultaneously spraying water to achieve a compost humidity of about $65-70 \%$ so that the mixture is moist and loose, but not smearing. The prepared composts are kept for 3-4 months. The finished compost is thoroughly mixed and a sample is taken for analysis. After positive results of the analysis, the prepared compost is used on the land where cotton and grain crops will be grown before plowing, depending on the phosphorus content of 10-12 tons per hectare. Table 1 show the compositions of the finished organomineral fertilizers.

From the data in table 1 it can be seen that using low-grade phosphorites and animal waste, it is possible to obtain a high-quality phosphorus-containing organomineral fertilizer.

It is known that the main criterion for the effectiveness of phosphorus fertilizers is the content of the total and relative content of the assimilable form of phosphorus, and in the case of the effectiveness of phosphorus-containing organomineral fertilizers, it is assessed by the content of organic substances, the degree of its humification, by the content of phosphorus and its assimilability by plants. In addition, at present, not every farm or large clusters with more than 100 hectares of land have the opportunity to apply 10-12 tons per 1 hectare of organic fertilizer [20]. It should also be noted that over the past few years, the methods for assessing the effectiveness of agricultural production technologies have fundamentally changed. If earlier economic indicators were the priority, now environmental indicators have taken the first place. These indicators do not contradict each other, for a long time and have been successfully used in countries with developed agricultural production. Each technology included in the list of recommended technologies for implementation must first meet the requirements for minimizing losses and harmful emissions to the environment, and then be evaluated for the economic efficiency of its use in specific conditions [8].

As already noted, various additives are added to obtain a more effective fertilizer and to reduce the release of harmful gases into the environment when composting cattle manure. The results of studies [16-18] showed that phosphorites are one of the best additives, but due to the difficulty of dissolving phosphates in or- 
ganic acids of manure with an increase in the amount of phosphate raw materials in the compost mass, the digestible form of phosphorus decreases sharply, and at low amounts of phosphorite in compost, the release of harmful gases into the atmosphere remains high. To obtain organomineral fertilizers based on cattle manure and phosphate raw materials with a higher content of phosphorus and other nutrients and to reduce the release of various gases into the environment, it is necessary to partially activate the phosphate raw materials with nitric acid. A feature of the process of nitric acid decomposition of phosphate raw materials is that nitric acid, decomposing natural phosphorites, then enters the composition of fertilizers as a useful nitrogencontaining component.

The decomposition of phosphate raw materials with nitric acid can be expressed by the following equation [21].

$\mathrm{Ca}_{5}\left(\mathrm{PO}_{4}\right)_{3} \mathrm{~F}+10 \mathrm{HNO}_{3}=3 \mathrm{H}_{3} \mathrm{PO}_{4}+5 \mathrm{Ca}\left(\mathrm{NO}_{3}\right)_{2}+\mathrm{HF}$

At low rates of nitric acid, calcium carbonates decompose primarily:

$\mathrm{CaCO}_{3}+2 \mathrm{HNO}_{3} \rightarrow \mathrm{Ca}\left(\mathrm{NO}_{3}\right)_{2}+\mathrm{H}_{2} \mathrm{O}+\mathrm{CO}_{2}$

At the same time, but to a lesser extent, the phosphate mineral is also decomposed:

$$
\begin{aligned}
& \mathrm{Ca}_{5} \mathrm{~F}\left(\mathrm{PO}_{4}\right)_{3}+\mathrm{HNO}_{3} \rightarrow \mathrm{Ca}\left(\mathrm{H}_{2} \mathrm{PO}_{4}\right)_{2}+\mathrm{Ca}\left(\mathrm{NO}_{3}\right)_{2}+\mathrm{HF} \\
& \mathrm{Ca}_{5} \mathrm{~F}\left(\mathrm{PO}_{4}\right)_{3}+\mathrm{HNO}_{3} \rightarrow \mathrm{CaHPO}_{4}+\mathrm{Ca}\left(\mathrm{NO}_{3}\right)_{2}+\mathrm{HF}
\end{aligned}
$$

It can be seen from the above reactions that activated phosphorite with nitric acid contains in its composition water-soluble calcium nitrate, monocalcium phosphate and assimilable dicalcium phosphate; in addition, the $\mathrm{pH}$ of the medium also decreases. When composting cattle manure with the addition of activated phosphorite with nitric acid in composts, a more optimal condition is created for the formation of highquality organic-mineral fertilizers with minimal release of harmful gases into the environment.

Based on the above, in order to obtain a more concentrated fertilizer in terms of the content of the assimilable form of phosphorus and to minimize the emission of harmful gases, the processes of obtaining organomineral fertilizers by composting cattle manure with the addition of activated phosphate raw materials with nitric acid have been studied.

\section{Experimental part}

For the study, the processes of obtaining organic fertilizers, cattle manure was used having a composition (wt.\%): Moisture - 72,36; ash - 4,43; organic matter $-23,21$; humic acids $-2,51$; fulvic acids -2,63; water-soluble organic substances $-2,34$; $\mathrm{P}_{2} \mathrm{O}_{5} 0,22 ; \mathrm{N}-0,46 ; \mathrm{K}_{2} \mathrm{O}-0,58 ; \mathrm{CaO}-0,43$, mineralized mass (MM) having the composition (wt.\%): $\mathrm{P}_{2} \mathrm{O}_{5}$ total was used as phosphate feedstock - 15,12; $\mathrm{CaO}_{-}$ 46,$02 ; \mathrm{MgO}-1,19 ; \mathrm{Fe}_{2} \mathrm{O}_{3}-0,88 ; \mathrm{Al}_{2} \mathrm{O}_{3} 1,10 ; \mathrm{SO}_{3}-$ 2,$72 ; \mathrm{CO}_{2}-1,28$; insoluble residue $-13,31$ and $59 \%$ nitric acid. At the first stage of the work, the mineralized mass was activated with nitric acid, the rate of nitric acid was varied in the range of $20-60 \%$ of stoichiometry for the decomposition of $\mathrm{CaCO}_{3}$ of the mineralized mass. At a rate of acid of $40 \%$ of stoichiometry, $60,55 \mathrm{~g}$ of $59 \% \mathrm{HNO}_{3}$ is required to process $100 \mathrm{~g}$ of mineralized mass. Processing of phosphate rock with nitric acid was carried out in solid-phase mode in a laboratory setup consisting of a tubular glass reactor equipped with a stirrer. After applying nitric acid (10-15 minutes), the reaction mass was thoroughly mixed for 30 minutes. Due to the exothermicity of the reaction, the temperature of the reaction mixture rose to $70{ }^{\circ} \mathrm{C}$. Depending on the norm of nitric acid, activated phosphorite was loose (at the norm of nitric acid $-20,30,40 \%$ ), loose, but having wet lumps (at the norm of nitric acid - 50,60\%). Activated phosphorite with nitric acid was dried at room temperature and analyzed for the content of the main components according to standard methods. The determination of all forms of $\mathrm{P}_{2} \mathrm{O}_{5}$ was carried out in accordance with GOST 20851.2-75. The $\mathrm{CaO}$ content was determined complexometrically: by titration with $0,05 \mathrm{~N}$ Trilon B solution of Trilon B in the presence of the fluorexon indicator. The results of the analysis are shown in Table 4, from which it can be seen that with an increase in the norm of nitric acid in the products, the content of the general form $\mathrm{P}_{2} \mathrm{O}_{5}$ decreases, and $\mathrm{P}_{2} \mathrm{O}_{5 \text { ass }}$. according to Trilon $\mathrm{B}$ and in a $2 \%$ citric acid solution, as well as the nitrogen content increases. If at the rate of $\mathrm{HNO}_{3} 20 \%$ the relative content of $\mathrm{P}_{2} \mathrm{O}_{5 \text { ass }}$. for Trilon $\mathrm{B}$ and in a $2 \%$ citric acid solution, it increases from the initial 15,39 and 7,56\% to 24,32 and $16,585 \%$, respectively, then these figures in the case of using $60 \%$ of the $\mathrm{HNO}_{3}$ norm reach 37,16 and $30,12 \%$. These products of decomposition of phosphate raw materials with nitric acid, obtained at different rates, were used as a phosphorus-containing component in the production of organomineral fertilizers based on cattle manure.

Compost based on cattle manure and activated phosphate raw materials with nitric acid are prepared in the following weight ratios for manure: activated phosphorite (AP) $=95: 5 ; 90: 10 ; 85: 15 ; 80: 20$; $75: 25 ; 70: 30$. The resulting mixtures were placed in containers with a volume of 2,0 liters by adding water based on the calculation to achieve a moisture con- 
The composition of organic fertilizers obtained by composting cattle manure and phosphorites of the Central Kyzyl Kum

\begin{tabular}{lcc}
\hline \multirow{2}{*}{ Components } & \multicolumn{2}{c}{ Types of raw materials and their ratio } \\
\cline { 2 - 3 } & Cattle manure: $\mathbf{M M}=\mathbf{1 0 0}: \mathbf{1 0}$ & Cattle manure : $\mathbf{S H F}=\mathbf{1 0 0}: \mathbf{1 0}$ \\
\hline $\mathrm{P}_{2} \mathrm{O}_{5}$ total, \% & 1,33 & 1,18 \\
$\mathrm{P}_{2} \mathrm{O}_{5}$ assimilated according to Trilon B, \% & 0,74 & 0,85 \\
Organic matter (total), $\%$ & 14,45 & 17,25 \\
Humic acids, \% & 3,17 & 3,11 \\
Fulvic acids, $\%$ & 3,29 & 3,27 \\
Water-soluble organic matter,\% & 3,05 & 2,99 \\
Nitrogen, $\%$ & 0,32 & 0,35 \\
$\mathrm{~K}_{2} \mathrm{O}, \%$ & 0,48 & 0,52 \\
CaO total, $\%$ & 3,89 & 3,91 \\
Moisture, $\%$ & 72,5 & 67,91 \\
\hline
\end{tabular}

tent of up to $60-70 \%$. A thin layer of soil was poured on top of the mixture. Samples were taken every 15 days and the composts were chemically analyzed. Determination of all forms of $\mathrm{P}_{2} \mathrm{O}_{5}$ was performed by weight method by precipitation of the phosphate ion with a magnesia mixture in the form of magnesium ammonium phosphate, followed by calcination of the precipitate at $1000-1050{ }^{\circ} \mathrm{C}$ according to GOST 20851.2-75.

Humidity was determined according to GOST 26712-85, ash content according to GOST 2671485 and organic matter according to GOST 27980-80. The total nitrogen content in compost was determined by mineralization of the analyzed fertilizer when heated with concentrated sulfuric acid in the presence of hydrogen peroxide, a mixed catalyst in sulfuric acid, followed by distillation of ammonia into a boric acid solution and titration with sulfuric acid GOST 26715-85. The amount of water-soluble fraction of organic substances extracted from the products by water was determined by filtration and evaporation in a water bath, drying the solid residue to a constant weight, and then burning it to determine the ash content and subtracting it. Humic acids were isolated by treating the products with $0,1 \mathrm{~N}$ alkali solution followed by acidification of the solution with mineral acid [22]. The solid phase after separation of alkali-soluble organic substances from it contains residual organic matter. It was thoroughly washed with distilled water, dried to constant weight, and the content of organic matter was determined. The difference between the amounts of alkali-soluble organic substances and humic acids gives us the fulvic acid content.

\section{Results and discussions}

Tables $2-3$ show changes in the total and relative contents of assimilable forms of $\mathrm{P}_{2} \mathrm{O}_{5}$ by Trilon $\mathrm{B}$ and $2 \%$ citric acid, depending on the norm nitric acid, the duration of composting and the weight ratios of the starting components. They show that an increase in the mass fraction of AF in relation to manure in composts contributes to an increase in the content of the total form of $\mathrm{P}_{2} \mathrm{O}_{5}$ and a decrease in the relative assimilable form of $\mathrm{P}_{2} \mathrm{O}_{5}$. With an increase in the norm of nitric acid and the duration of composting, the relative content of the assimilable form of $\mathrm{P}_{2} \mathrm{O}_{5}$ increases. In the initial MM, the relative content of $\mathrm{P}_{2} \mathrm{O}_{5}$ for trilon $\mathrm{B}$ and $2 \%$ citric acid is 15,39 and $7,56 \%$, after activation with nitric acid at a rate of $40 \%$ these indicators increase to 32,19 and $25,27 \%$, and after composting in the same norm of nitric acid and with the ratio of manure: $\mathrm{AF}=75: 25$ and compost exposure for 30 days, these indicators increase to 44,44 and $36,50 \%$, after 60 days $-60,27$ and 51,46\%, and after 90 days to 68,01 and 59,12\%, respectively. At a nitric acid rate of $20 \%$, the ratio of manure: AF $=95: 5$ and compost exposure for 90 days, the relative content of $\mathrm{P}_{2} \mathrm{O}_{5}$ ass. for Trilon $\mathrm{B}$ and $2 \%$ citric acid, they increase from the initial 15,39 and $7,56 \%$ to 71,38 and $62,35 \%$, and at a nitric acid rate of $60 \%$, these indicators increase to 77,38 and $68,92 \%$. That is, with an increase in the rate of nitric acid and the duration of composting, the degree of transition of phosphorus from the indigestible form to the form assimilable for plants increases markedly. Tables $4-5$ show the results of changes in the content of humic acids, fulvic 
The composition of the activated mineralized mass with nitric acid

\begin{tabular}{|c|c|c|c|c|c|c|c|}
\hline 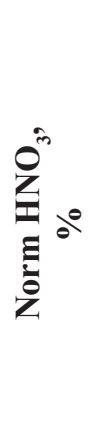 & 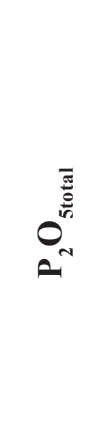 & $\overbrace{}^{\frac{\bar{g}}{\tilde{g}}}$ & 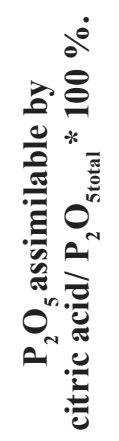 & 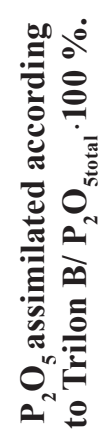 & 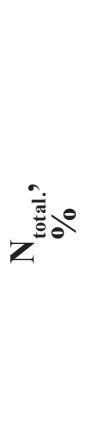 & $\theta^{-}$ & 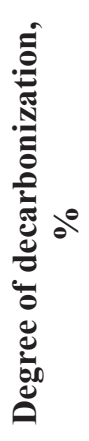 \\
\hline 0 & 15,12 & 46,02 & 7,56 & 15,39 & - & 15,28 & - \\
\hline 20 & 13,29 & 40,44 & 16,58 & 24,32 & 1,70 & 11,51 & 14,29 \\
\hline 30 & 12,53 & 38,12 & 21,33 & 28,41 & 2,41 & 9,95 & 21,43 \\
\hline 40 & 11,85 & 36,06 & 25,27 & 32,19 & 3,03 & 8,55 & 28,57 \\
\hline 50 & 11,24 & 34,21 & 28,46 & 35,41 & 3,59 & 7,30 & 35,71 \\
\hline 60 & 10,69 & 32,54 & 30,12 & 37,16 & 4,09 & 6,17 & 42,86 \\
\hline
\end{tabular}

Table 3

The content of phosphorus $\left(\mathrm{P}_{2} \mathrm{O}_{5}\right.$ total, $\mathrm{P}_{2} \mathrm{O}_{5}$ assimilable by citric acid/ $\mathrm{P}_{2} \mathrm{O}_{5 \text { total }}, \mathrm{P}_{2} \mathrm{O}_{5}$ assimilated according to Trilon $\mathrm{B} / \mathbf{P}_{2} \mathrm{O}_{5 \text { total }}$ ) in composts prepared on the basis of cattle manure with the addition of an activated mineralized mass with nitric acid, depending on the exposure time and mass ratios, \%

\begin{tabular}{|c|c|c|c|c|c|c|c|c|c|c|}
\hline \multirow{3}{*}{$\begin{array}{c}\text { Mass ratio } \\
\text { Cattle } \\
\text { manure: AP }\end{array}$} & \multicolumn{10}{|c|}{ Duration of composting, days } \\
\hline & 1 & 30 & 60 & 90 & 30 & 60 & 90 & 30 & 60 & 90 \\
\hline & \multicolumn{4}{|c|}{$\mathbf{P}_{2} \mathbf{O}_{5 \text { total. }} \%$} & \multicolumn{3}{|c|}{$\begin{array}{l}\mathrm{P}_{2} \mathrm{O}_{5} \text { assimilable by citric } \\
\text { acid } / \mathrm{P}_{2} \mathrm{O}_{5 \text { total }} \cdot 100 \%\end{array}$} & \multicolumn{3}{|c|}{$\begin{array}{l}\mathrm{P}_{2} \mathrm{O}_{5} \text { assimilated according } \\
\text { to Trilon } \mathrm{B} / \mathrm{P}_{2} \mathrm{O}_{5 \text { total }} \cdot 100 \%\end{array}$} \\
\hline \multicolumn{11}{|c|}{ Without activation with nitric acid (Mineralized mass) } \\
\hline $95: 5$ & 0,919 & 0,930 & 0,947 & 0,959 & 27,17 & 45,65 & 56,52 & 34,88 & 54,84 & 65,52 \\
\hline $90: 10$ & 1,555 & 1,569 & 1,592 & 1,607 & 25,81 & 43,87 & 53,55 & 34,02 & 53,07 & 63,03 \\
\hline $85: 15$ & 2,135 & 2,151 & 2,175 & 2,190 & 25,82 & 42,72 & 51,17 & 33,75 & 51,53 & 60,83 \\
\hline $80: 20$ & 2,667 & 2,683 & 2,707 & 2,721 & 24,34 & 40,45 & 48,69 & 32,47 & 49,57 & 58,12 \\
\hline $75: 25$ & 3,156 & 3,169 & 3,187 & 3,197 & 23,73 & 39,24 & 46,52 & 31,85 & 48,16 & 56,15 \\
\hline $70: 30$ & 3,608 & 3,618 & 3,632 & 3,640 & 22,99 & 36,84 & 43,77 & 30,95 & 45,95 & 53,14 \\
\hline \multicolumn{11}{|c|}{ Norm $\mathrm{HNO}_{3}, 20 \%$} \\
\hline $95: 5$ & 0,848 & 0,857 & 0,873 & 0,884 & 31,76 & 51,76 & 62,35 & 39,25 & 60,18 & 71,38 \\
\hline $90: 10$ & 1,427 & 1,440 & 1,460 & 1,474 & 30,77 & 50,35 & 60,14 & 38,87 & 58,79 & 69,21 \\
\hline $85: 15$ & 1,964 & 1,979 & 2,000 & 2,014 & 30,61 & 48,98 & 58,16 & 38,60 & 57,50 & 67,38 \\
\hline $80: 20$ & 2,464 & 2,479 & 2,500 & 2,513 & 29,67 & 46,75 & 55,28 & 37,61 & 55,46 & 64,38 \\
\hline $75: 25$ & 2,931 & 2,943 & 2,959 & 2,968 & 29,35 & 45,39 & 53,24 & 37,21 & 54,10 & 62,36 \\
\hline $70: 30$ & 3,367 & 3,376 & 3,388 & 3,395 & 29,08 & 44,51 & 51,63 & 37,03 & 53,05 & 60,72 \\
\hline \multicolumn{11}{|c|}{ Norm $\mathrm{HNO}_{3}, 30 \%$} \\
\hline $95: 5$ & 0,815 & 0,824 & 0,838 & 0,848 & 35,37 & 54,88 & 64,63 & 42,88 & 63,06 & 73,85 \\
\hline $90: 10$ & 1,369 & 1,381 & 1,400 & 1,412 & 35,04 & 54,01 & 63,50 & 42,86 & 62,34 & 72,52 \\
\hline $85: 15$ & 1,879 & 1,893 & 1,913 & 1,925 & 34,57 & 52,13 & 61,17 & 42,56 & 60,76 & 70,28 \\
\hline
\end{tabular}


Continuation of Table 3.

\begin{tabular}{|c|c|c|c|c|c|c|c|c|c|c|}
\hline $80: 20$ & 2,373 & 2,387 & 2,406 & 2,418 & 33,76 & 49,79 & 57,81 & 41,66 & 58,45 & 66,85 \\
\hline $75: 25$ & 2,830 & 2,840 & 2,855 & 2,863 & 33,57 & 49,12 & 56,89 & 41,50 & 57,86 & 65,86 \\
\hline $70: 30$ & 3,261 & 3,269 & 3,280 & 3,286 & 33,13 & 47,85 & 54,91 & 41,05 & 56,52 & 63,94 \\
\hline \multicolumn{11}{|c|}{ Norm $\mathrm{HNO}_{3}, 40 \%$} \\
\hline $95: 5$ & 0,786 & 0,794 & 0,808 & 0,817 & 37,97 & 56,96 & 67,09 & 45,45 & 65,11 & 75,62 \\
\hline $90: 10$ & 1,317 & 1,328 & 1,346 & 1,357 & 37,12 & 56,06 & 65,15 & 45,25 & 64,33 & 74,31 \\
\hline $85: 15$ & 1,819 & 1,832 & 1,850 & 1,862 & 37,91 & 54,40 & 63,19 & 45,72 & 63,22 & 72,37 \\
\hline $80: 20$ & 2,294 & 2,307 & 2,325 & 2,336 & 37,12 & 53,28 & 61,14 & 44,85 & 61,70 & 70,12 \\
\hline $75: 25$ & 2,743 & 2,753 & 2,766 & 2,773 & 36,50 & 51,46 & 59,12 & 44,44 & 60,27 & 68,01 \\
\hline $70: 30$ & 3,197 & 3,204 & 3,214 & 3,220 & 36,25 & 50,31 & 57,19 & 44,10 & 58,99 & 66,13 \\
\hline \multicolumn{11}{|c|}{ Norm $\mathrm{HNO}_{3}, 50 \%$} \\
\hline $95: 5$ & 0,763 & 0,771 & 0,783 & 0,792 & 39,47 & 57,89 & 67,11 & 47,35 & 66,83 & 77,25 \\
\hline $90: 10$ & 1,283 & 1,293 & 1,310 & 1,321 & 39,06 & 57,03 & 67,19 & 47,04 & 66,43 & 76,56 \\
\hline $85: 15$ & 1,767 & 1,778 & 1,795 & 1,806 & 38,98 & 55,93 & 64,97 & 47,10 & 64,92 & 74,24 \\
\hline $80: 20$ & 2,244 & 2,256 & 2,272 & 2,283 & 38,84 & 54,91 & 62,95 & 46,72 & 63,79 & 72,33 \\
\hline $75: 25$ & 2,705 & 2,714 & 2,726 & 2,732 & 38,15 & 52,59 & 60,00 & 46,13 & 61,74 & 69,38 \\
\hline $70: 30$ & 3,120 & 3,126 & 3,134 & 3,139 & 37,82 & 51,60 & 58,01 & 45,89 & 60,58 & 67,62 \\
\hline \multicolumn{11}{|c|}{ Norm $\mathrm{HNO}_{3}, 60$ \% } \\
\hline $95: 5$ & 0,744 & 0,751 & 0,763 & 0,772 & 40,54 & 59,46 & 68,92 & 48,95 & 67,47 & 77,38 \\
\hline $90: 10$ & 1,242 & 1,252 & 1,268 & 1,278 & 41,13 & 58,87 & 67,74 & 48,79 & 67,14 & 76,74 \\
\hline $85: 15$ & 1,722 & 1,733 & 1,748 & 1,758 & 40,70 & 57,56 & 66,28 & 48,72 & 66,29 & 75,47 \\
\hline $80: 20$ & 2,183 & 2,194 & 2,210 & 2,219 & 40,37 & 55,96 & 63,76 & 48,32 & 64,56 & 72,68 \\
\hline $75: 25$ & 2,627 & 2,635 & 2,646 & 2,652 & 39,16 & 53,61 & 60,46 & 47,09 & 62,12 & 69,48 \\
\hline $70: 30$ & 3,055 & 3,060 & 3,067 & 3,071 & 38,89 & 51,96 & 58,17 & 46,58 & 60,51 & 67,19 \\
\hline
\end{tabular}

acids and water-soluble organic substances depending on the norm of nitric acid, exposure time and weight ratios of the initial components. From the data presented it can be seen that with an increase in the duration of composting, the content of the above substances in manure-phosphorite composts noticeably increases. At a norm of nitric acid of $40 \%$ and a ratio of manure: $\mathrm{AF}=75: 25$ after 30 days in the compost the content of humic acids, fulvic acids and water-soluble organic substances is $2,18 \%, 2,36 \%, 2,09 \%$, then after 60 days $-2,51 \%, 2,91 \%, 2,62 \%$, and after 90 days $3,14 \%, 3,20 \%, 2,89 \%$, respectively. Also, composting cattle manure with the addition of AF has a positive effect on the degree of humification of organic matter. If at a rate of nitric acid of $30 \%$ and a ratio of cattle manure: $\mathrm{AF}=95: 5$ after 90 days the degree of humification is $56,44 \%$, then at the same rate of nitric acid and a ratio of cattle manure: $\mathrm{AF}=85: 15$ after 90 days $58,94 \%$, and at a ratio of $70: 30$ after 90 days $64,06 \%$ (Table 4.). These data show that the preparation of composts based on cattle manure with the addition of AF has a positive effect on all composting indicators.

Figures 1 and 2 show the dependence of the loss of nitrogen and organic matter on the norm of ni- tric acid, the weight ratio of the initial components and the duration of the compost exposure. It can be seen from it that with an increase in the norm of nitric acid and the mass fraction of AF in the mixture, the loss of organic matter and nitrogen decreases noticeably. For example, at the rate of nitric acid of $20 \%$ and the ratio of manure: $\mathrm{AF}=95: 5$ after exposure for 90 days, the loss of organic matter and nitrogen is 14,57 and $18,79 \%$, and at the rate of nitric acid of $60 \%$ and the ratio of manure: $\mathrm{AF}=70: 30$ after 90 days, the loss of organic matter and nitrogen is only 2,78 and 3,62 \% (Figures 1 and 2). Based on considerations of the degree of transition to the digestible form of $\mathrm{P}_{2} \mathrm{O}_{5}$ of phosphate raw materials and the degree of humification of organic substances, the optimal compost preparation mode was determined: The norm of nitric acid for the activation of the initial phosphate raw material is $40 \%$ of the stoichiometry for the $\mathrm{CaCO} 3$ content, the ratio of Manure (cattle): $\mathrm{AF}=75: 25$, the moisture content of the composts during preparation is $60-65 \%$, the composting time is 3 months. In this case, the organomineral fertilizer has a composition (wt.\%): $\mathrm{P}_{2} \mathrm{O}_{5}$ total. $-2,78 ; \mathrm{P}_{2} \mathrm{O}_{5}$ ass. for Trilon $\mathrm{B}-2,78 ; \mathrm{P}_{2} \mathrm{O}_{5}$ ass. in citric acid - 2,78; or- 
The degree of humification of organic substances and content humic acids in composts prepared on the basis of cattle manure with the addition of an activated mineralized mass with nitric acid,

Table 4 depending on the holding time and mass ratios, \%

\begin{tabular}{|c|c|c|c|c|c|c|c|c|}
\hline \multirow{3}{*}{$\begin{array}{c}\text { Mass ratio } \\
\text { Cattle } \\
\text { manure: AP }\end{array}$} & \multicolumn{8}{|c|}{ Duration of composting, days } \\
\hline & 15 & 30 & 60 & 90 & 1 & 30 & 60 & 90 \\
\hline & \multicolumn{4}{|c|}{ Degree of humification of organic substances } & \multicolumn{4}{|c|}{ Humic acid } \\
\hline \multicolumn{9}{|c|}{ Without activation with nitric acid (Mineralized mass) } \\
\hline $95: 5$ & 35,51 & 39,49 & 49,77 & 55,62 & 2,27 & 2,80 & 3,55 & 3,97 \\
\hline $90: 10$ & 35,87 & 40,05 & 51,13 & 56,80 & 2,05 & 2,57 & 3,30 & 3,67 \\
\hline $85: 15$ & 36,12 & 40,79 & 52,47 & 58,18 & 1,86 & 2,37 & 3,06 & 3,40 \\
\hline $80: 20$ & 36,60 & 41,83 & 53,94 & 59,72 & 1,67 & 2,18 & 2,83 & 3,14 \\
\hline $75: 25$ & 36,90 & 42,74 & 55,58 & 61,41 & 1,51 & 2,02 & 2,63 & 2,91 \\
\hline $70: 30$ & 37,53 & 44,07 & 57,76 & 63,36 & 1,35 & 1,86 & 2,45 & 2,69 \\
\hline \multicolumn{9}{|c|}{ Norm $\mathrm{HNO}_{3}, 20 \%$} \\
\hline $95: 5$ & 35,59 & 39,61 & 50,03 & 55,94 & 2,32 & 2,87 & 3,64 & 4,08 \\
\hline $90: 10$ & 36,01 & 40,30 & 51,66 & 57,46 & 2,11 & 2,66 & 3,42 & 3,81 \\
\hline $85: 15$ & 36,12 & 40,83 & 52,61 & 58,37 & 1,92 & 2,45 & 3,17 & 3,53 \\
\hline $80: 20$ & 36,71 & 42,00 & 54,24 & 60,08 & 1,75 & 2,29 & 2,98 & 3,30 \\
\hline $75: 25$ & 36,89 & 42,76 & 55,66 & 61,53 & 1,58 & 2,11 & 2,76 & 3,06 \\
\hline $70: 30$ & 37,58 & 44,16 & 57,96 & 63,60 & 1,43 & 1,97 & 2,60 & 2,86 \\
\hline \multicolumn{9}{|c|}{ Norm $\mathrm{HNO}_{3}, 30 \%$} \\
\hline $95: 5$ & 35,65 & 39,76 & 50,40 & 56,44 & 2,33 & 2,89 & 3,68 & 4,13 \\
\hline $90: 10$ & 36,03 & 40,35 & 51,80 & 57,65 & 2,13 & 2,68 & 3,47 & 3,86 \\
\hline $85: 15$ & 36,23 & 41,04 & 53,06 & 58,94 & 1,94 & 2,49 & 3,23 & 3,60 \\
\hline $80: 20$ & 36,80 & 42,19 & 54,67 & 60,62 & 1,78 & 2,34 & 3,05 & 3,39 \\
\hline $75: 25$ & 37,06 & 43,06 & 56,25 & 62,25 & 1,62 & 2,18 & 2,86 & 3,17 \\
\hline $70: 30$ & 37,62 & 44,31 & 58,32 & 64,06 & 1,46 & 2,02 & 2,67 & 2,94 \\
\hline \multicolumn{9}{|c|}{ Norm $\mathrm{HNO}_{3}, 40 \%$} \\
\hline $95: 5$ & 35,38 & 39,19 & 49,05 & 54,65 & 2,34 & 2,86 & 3,60 & 4,02 \\
\hline $90: 10$ & 35,78 & 39,81 & 50,47 & 55,92 & 2,15 & 2,67 & 3,41 & 3,78 \\
\hline $85: 15$ & 35,99 & 40,49 & 51,73 & 57,23 & 1,98 & 2,50 & 3,22 & 3,56 \\
\hline $80: 20$ & 36,54 & 41,60 & 53,32 & 58,92 & 1,81 & 2,35 & 3,03 & 3,35 \\
\hline $75: 25$ & 36,73 & 42,37 & 54,78 & 60,42 & 1,65 & 2,18 & 2,84 & 3,14 \\
\hline $70: 30$ & 37,31 & 43,63 & 56,88 & 62,30 & 1,51 & 2,06 & 2,70 & 2,96 \\
\hline \multicolumn{9}{|c|}{ Norm $\mathrm{HNO}_{3}, 50 \%$} \\
\hline $95: 5$ & 35,11 & 38,65 & 47,79 & 52,98 & 2,36 & 2,85 & 3,55 & 3,94 \\
\hline $90: 10$ & 35,51 & 39,26 & 49,19 & 54,26 & 2,19 & 2,69 & 3,39 & 3,74 \\
\hline $85: 15$ & 35,75 & 39,96 & 50,48 & 55,62 & 2,01 & 2,51 & 3,19 & 3,52 \\
\hline $80: 20$ & 36,23 & 40,97 & 51,97 & 57,21 & 1,86 & 2,38 & 3,04 & 3,35 \\
\hline $75: 25$ & 36,47 & 41,79 & 53,49 & 58,81 & 1,71 & 2,23 & 2,87 & 3,16 \\
\hline $70: 30$ & 36,99 & 42,91 & 55,31 & 60,38 & 1,55 & 2,08 & 2,69 & 2,95 \\
\hline \multicolumn{9}{|c|}{ Norm $\mathrm{HNO}_{3}, 60 \%$} \\
\hline $95: 5$ & 34,93 & 38,24 & 46,82 & 51,69 & 2,38 & 2,84 & 3,50 & 3,88 \\
\hline $90: 10$ & 35,29 & 38,82 & 48,17 & 52,94 & 2,21 & 2,68 & 3,35 & 3,69 \\
\hline $85: 15$ & 35,52 & 39,49 & 49,43 & 54,28 & 2,05 & 2,53 & 3,19 & 3,51 \\
\hline $80: 20$ & 35,93 & 40,36 & 50,64 & 55,54 & 1,89 & 2,39 & 3,01 & 3,31 \\
\hline $75: 25$ & 36,26 & 41,26 & 52,27 & 57,27 & 1,74 & 2,24 & 2,85 & 3,13 \\
\hline $70: 30$ & 36,64 & 42,09 & 53,51 & 58,18 & 1,60 & 2,10 & 2,69 & 2,93 \\
\hline
\end{tabular}


The content of fulvic acid and water-soluble organic substances in composts prepared on the basis of cattle manure with the addition of an activated mineralized mass with nitric acid, depending on the exposure time and mass ratios, \%

\begin{tabular}{|c|c|c|c|c|c|c|c|c|}
\hline \multirow{3}{*}{$\begin{array}{c}\text { Mass ratio } \\
\text { Cattle manure: } \\
\text { AP }\end{array}$} & \multicolumn{7}{|c|}{ Duration of composting, days } & \multirow[b]{2}{*}{90} \\
\hline & 1 & 30 & 60 & 90 & 1 & 30 & 60 & \\
\hline & \multicolumn{4}{|c|}{ Fulvic acid } & \multicolumn{4}{|c|}{ Water-soluble organic substances } \\
\hline \multicolumn{9}{|c|}{ Without activation with nitric acid (Mineralized mass) } \\
\hline $95: 5$ & 2,38 & 2,90 & 3,63 & 4,05 & 2,12 & 2,60 & 3,27 & 3,66 \\
\hline $90: 10$ & 2,15 & 2,66 & 3,38 & 3,75 & 1,91 & 2,38 & 3,04 & 3,37 \\
\hline $85: 15$ & 1,94 & 2,44 & 3,12 & 3,46 & 1,73 & 2,19 & 2,82 & 3,12 \\
\hline $80: 20$ & 1,75 & 2,26 & 2,90 & 3,21 & 1,56 & 2,03 & 2,61 & 2,89 \\
\hline $75: 25$ & 1,58 & 2,08 & 2,69 & 2,97 & 1,40 & 1,86 & 2,41 & 2,67 \\
\hline $70: 30$ & 1,42 & 1,93 & 2,52 & 2,76 & 1,26 & 1,72 & 2,26 & 2,48 \\
\hline \multicolumn{9}{|c|}{ Norm $\mathrm{HNO}_{3}, 20 \%$} \\
\hline $95: 5$ & 2,43 & 2,96 & 3,72 & 4,16 & 2,16 & 2,65 & 3,35 & 3,74 \\
\hline $90: 10$ & 2,21 & 2,75 & 3,50 & 3,89 & 1,97 & 2,46 & 3,16 & 3,51 \\
\hline $85: 15$ & 2,01 & 2,53 & 3,25 & 3,60 & 1,79 & 2,27 & 2,93 & 3,25 \\
\hline $80: 20$ & 1,83 & 2,37 & 3,04 & 3,37 & 1,63 & 2,12 & 2,74 & 3,04 \\
\hline $75: 25$ & 1,66 & 2,19 & 2,84 & 3,13 & 1,47 & 1,95 & 2,54 & 2,81 \\
\hline $70: 30$ & 1,50 & 2,04 & 2,67 & 2,92 & 1,33 & 1,82 & 2,39 & 2,62 \\
\hline \multicolumn{9}{|c|}{ Norm $\mathrm{HNO}_{3}, 30 \%$} \\
\hline $95: 5$ & 2,44 & 2,99 & 3,77 & 4,21 & 2,17 & 2,67 & 3,39 & 3,80 \\
\hline $90: 10$ & 2,23 & 2,78 & 3,55 & 3,94 & 1,99 & 2,49 & 3,20 & 3,56 \\
\hline $85: 15$ & 2,03 & 2,57 & 3,31 & 3,67 & 1,81 & 2,31 & 2,98 & 3,31 \\
\hline $80: 20$ & 1,86 & 2,42 & 3,12 & 3,45 & 1,66 & 2,17 & 2,81 & 3,12 \\
\hline $75: 25$ & 1,69 & 2,24 & 2,91 & 3,22 & 1,51 & 2,02 & 2,63 & 2,91 \\
\hline $70: 30$ & 1,53 & 2,09 & 2,74 & 3,01 & 1,37 & 1,88 & 2,48 & 2,72 \\
\hline \multicolumn{9}{|c|}{ Norm $\mathrm{HNO}_{3}, 40 \%$} \\
\hline $95: 5$ & 2,45 & 2,96 & 3,68 & 4,10 & 2,18 & 2,65 & 3,32 & 3,70 \\
\hline $90: 10$ & 2,25 & 2,76 & 3,48 & 3,85 & 2,01 & 2,48 & 3,15 & 3,49 \\
\hline $85: 15$ & 2,07 & 2,58 & 3,28 & 3,63 & 1,84 & 2,31 & 2,95 & 3,27 \\
\hline $80: 20$ & 1,90 & 2,43 & 3,10 & 3,42 & 1,69 & 2,18 & 2,79 & 3,08 \\
\hline $75: 25$ & 1,73 & 2,26 & 2,91 & 3,20 & 1,54 & 2,03 & 2,62 & 2,89 \\
\hline $70: 30$ & 1,59 & 2,14 & 2,78 & 3,04 & 1,41 & 1,91 & 2,49 & 2,73 \\
\hline \multicolumn{9}{|c|}{ Norm $\mathrm{HNO}_{3}, 50 \%$} \\
\hline $95: 5$ & 2,47 & 2,95 & 3,62 & 4,01 & 2,20 & 2,64 & 3,26 & 3,62 \\
\hline $90: 10$ & 2,30 & 2,79 & 3,47 & 3,82 & 2,04 & 2,49 & 3,12 & 3,44 \\
\hline $85: 15$ & 2,11 & 2,60 & 3,27 & 3,59 & 1,88 & 2,33 & 2,94 & 3,24 \\
\hline $80: 20$ & 1,95 & 2,46 & 3,11 & 3,42 & 1,73 & 2,20 & 2,79 & 3,07 \\
\hline $75: 25$ & 1,79 & 2,31 & 2,94 & 3,23 & 1,60 & 2,08 & 2,66 & 2,92 \\
\hline $70: 30$ & 1,63 & 2,16 & 2,77 & 3,02 & 1,45 & 1,93 & 2,49 & 2,72 \\
\hline \multicolumn{9}{|c|}{ Norm $\mathrm{HNO}_{3}, 60$ \% } \\
\hline $95: 5$ & 2,50 & 2,95 & 3,59 & 3,96 & 2,22 & 2,64 & 3,23 & 3,56 \\
\hline $90: 10$ & 2,32 & 2,78 & 3,43 & 3,76 & 2,06 & 2,49 & 3,08 & 3,39 \\
\hline $85: 15$ & 2,15 & 2,62 & 3,26 & 3,57 & 1,91 & 2,34 & 2,93 & 3,22 \\
\hline $80: 20$ & 1,98 & 2,47 & 3,08 & 3,37 & 1,77 & 2,22 & 2,78 & 3,05 \\
\hline $75: 25$ & 1,83 & 2,33 & 2,93 & 3,21 & 1,63 & 2,08 & 2,64 & 2,89 \\
\hline $70: 30$ & 1,67 & 2,17 & 2,74 & 2,98 & 1,49 & 1,95 & 2,47 & 2,69 \\
\hline
\end{tabular}




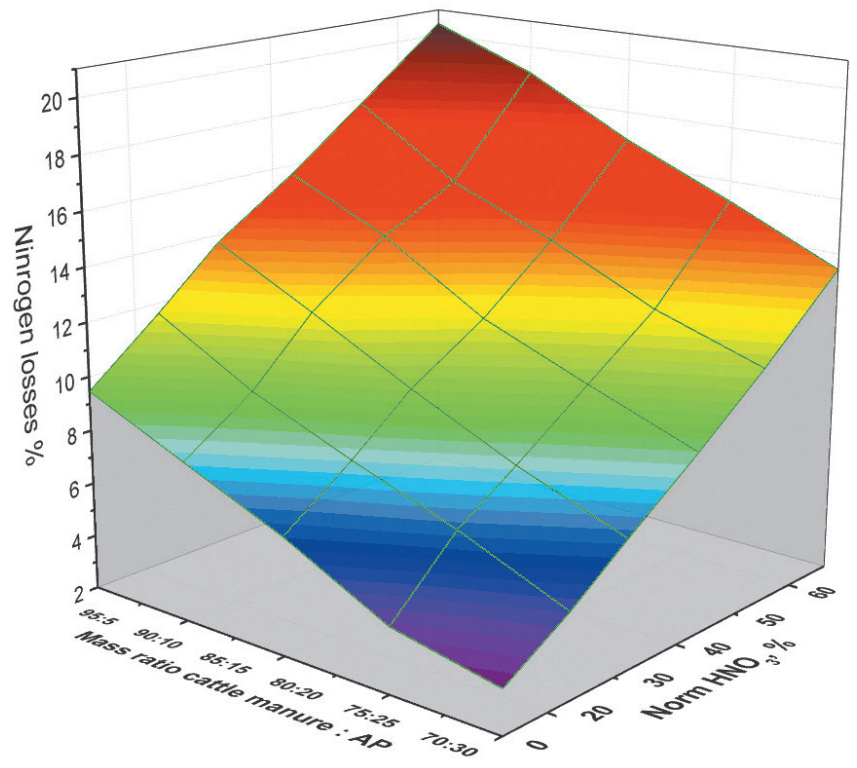

Fig. 1. Nitrogen losses in composts after 90 days of exposure, prepared on the basis of cattle manure with the addition of an activated mineralized mass, depending on the norm of nitric acid and mass ratios, $\%$

ganic matter - 16,94; humic acids - 3,67; fulvic acids - 3,94; water-soluble organic matter - 3,34; nitrogen $-0,92$; moisture $-63,61$. The degree of humification of organic substances is $60,42 \%$, the loss of nitrogen is 8,19 , and the loss of organic matter is 5,50 .

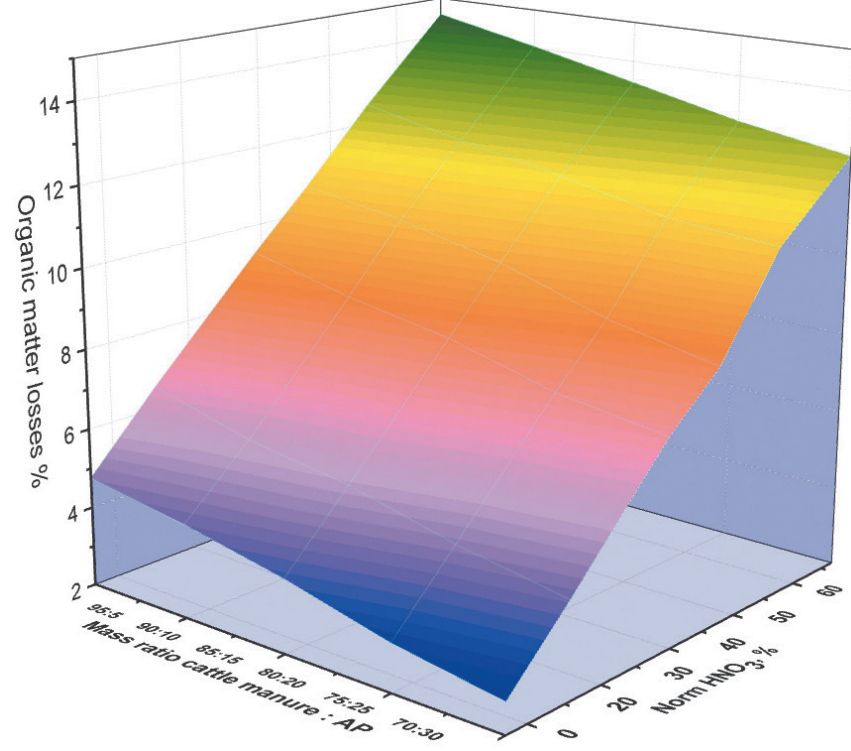

Fig. 2. Organic matter losses in composts after 90 days of exposure, prepared on the basis of cattle manure with the addition of activated mineralized mass, depending on the rate of nitric acid and mass ratios, \%

Table 6 shows the compositions for comparing the indicators of organic mineral fertilizers obtained under optimal conditions by composting cattle manure, cattle manure with the addition of MM, SHF and AF. The table shows that when using activated phospho-

Table 6

The composition of organomineral fertilizers obtained by composting cattle manure, cattle manure with the addition of phosphorites of the Central Kyzyl Kum

\begin{tabular}{lcccc}
\hline & \multicolumn{4}{c}{ Types of source components } \\
\cline { 2 - 4 } \multicolumn{1}{c}{ Components } & Cattle manure & $\begin{array}{c}\text { Cattle manure: } \\
\text { MM }\end{array}$ & $\begin{array}{c}\text { Cattle manure: } \\
\text { SHF }\end{array}$ & $\begin{array}{c}\text { Cattle manure: } \\
\text { AF }\end{array}$ \\
\hline $\mathrm{P}_{2} \mathrm{O}_{5}$ total, \% & 0,25 & 1,33 & 1,18 & 2,77 \\
$\mathrm{P}_{2} \mathrm{O}_{5}$ assimilated according to Trilon B, \%. & - & 0,74 & 0,85 & 1,64 \\
$\mathrm{P}_{2} \mathrm{O}_{5}$ assimilable by citric acid, \%. & - & 0,69 & 0,73 & 1,89 \\
Organic matter (total),\% & 17,53 & 14,45 & 17,25 & 14,43 \\
Humic acids,\% & 3,19 & 3,17 & 3,11 & 3,14 \\
Fulvic acids, $\%$ & 3,42 & 3,29 & 3,27 & 3,2 \\
Water-soluble organic matter,\% & 2,94 & 3,05 & 2,99 & 2,89 \\
Nitrogen,\% & 0,32 & 0,32 & 0,35 & 0,92 \\
$\mathrm{~K}_{2} \mathrm{O}, \%$ & 0,62 & 0,48 & 0,52 & 0,39 \\
CaO total,\% & 0,52 & 3,89 & 3,91 & 8,32 \\
Moisture,\% & 72,46 & 72,5 & 67,91 & 63,61 \\
Loss of organic substances, \% & 23,54 & 18,65 & 16,42 & 8,19 \\
Loss of nitrogen,\% & 28,67 & 14,68 & 12,87 & 5,5 \\
Degree of humification of organic & 41,64 & 57,32 & 53,06 & 60,42 \\
substances,\% & & & & \\
\hline
\end{tabular}


rite with nitric acid in the product, the content of total $\mathrm{P}_{2} \mathrm{O}_{5}$ is 2,08 times higher, the degree of humification of organic substances is 1,05 times, the loss of nitrogen and organic substances is less than 2,66 and 2,28 times than when using unactivated phosphorite.

\section{Conclusion}

Thus, the research results allow us to conclude that under optimal conditions, AF has the best properties for reducing the release of harmful gases to the environment, for increasing the humification of organic substances and for obtaining organomineral fertilizers with a higher phosphorus content based on animal waste, which is a prerequisite for the development of a waste-free and environmentally safe technology for obtaining phosphorus-containing organomineral fertilizers, and the involvement of low-grade phosphate raw materials in the production of organomineral fertilizers will significantly expand the phosphate raw material base.

\section{References}

1. Alimov U.K. Reymov A.M., Namazov Sh.S., Beglov B.M. Russian Journal of Applied Chemistry. 2010. V. 83. N. 3. P. 545-552. (in Russian).

2. Alimov U.K., Namazov S.S., Remov A.R. Journal of Chemical technology and Metallurgy. 2015. V. 50. N. 2. P. 163-170. (in Bulgaria).

3. Gridneva P.I. Gridneva T.T. Bulletin of the All-Russian Research Institute of Livestock Mechanization. 2017. N. 1 (25). P. 25-33. (in Russian).

4. Gridneva T.T. Bulletin of the All-Russian Research Institute of Livestock Mechanization. 2012. N. 4 (8). P. 61-68. (in Russian).

5. Gaiduk V.I., Komlatsky G.V. Scientific journal KubSAU. 2017. N.125 (01). P. 1-17. (in Russian).

6. Gridnev P.I., Gridneva T.T. Bulletin of the All-Russian Research Institute of Livestock Mechanization. 2019. N. 4 (36). P. 24-32. (in Russian).

7. Miroshnikova V.V., Miroshnikov M.A. Scientific journal of the Russian Research Institute of land reclamation problems. 2014. N. 2 (14). P. 150-165. (in Russian).
8. Gridnev P.I., Gridneva T.T. Bulletin of the All-Russian Research Institute of Livestock Mechanization. 2017. N. 3 (27). P. 159-163. (in Russian).

9. Román P., Martínez M.M., Pantoja A. Food and Agriculture organization of the united stations. 2015. P. 112. (in latin America).

10. Nozomi Yamamoto, Chika Tada, Yutaka Nakai. Journal of Integrated Field Science. 2011. N 8. P. 55-59. (in United States).

11. Borah Nilay, Deka N.C., Deka J., Barua I.C., Nath D.J., Medhi B.K. International Journal of Current Research. 2014. V. 6. N 8. P. 8026-8031. (in India)

12. Das S., Jeong S.T., Das S. and Kim P.J. Frontiers Microbiology. 2017. V. 8. P. 1702. DOI:10.3389/ fmicb.2017.01702 ( in Switzerland).

13. Das S., Adhya T.K. Geoderma. 2014 N. 213. P. 185192. DOI: $10.1016 /$ j.geoderma.2013.08.011. ( in Netherlands).

14. Roba T.B. Open Access Library Journal. 2018. N. 5. P. 1-11 DOI: 10.4236/oalib.1104618. (in British).

15. Temirov U., Namazov S., Kanoatov K., Usanbayev N., Azimova D. PalArch's Journal of Archaeology of Egypt / Egyptology. 2020. V. 17. N.6. 14343-14350. (in Netherlands).

16. Temirov U.Sh., Reymov A.M., Namazov Sh.S., Usanbaev N.H., Seytnazarov A.R. International Journal of Recent Advancement in Engineering \& Research. 2018. V. 4. N. 1. P. 39-46. (in India).

17. Temirov U.Sh., Ganiev P.H., Namazov Sh.S., Usanbaev N.Kh. Electronic scientific journal. Universum: chemistry and biology. 2018. N. 8 (50). P. 25-33. (in Russian).

18. Namazov S., Temirov U., Usanbayev $N$. International Journal of Innovative Technology and Exploring Engineering (IJITEE). 2019. V. 8. N. 12. P. 2260-2265. (in India).

19. Temirov U.Sh., Namazov Sh.S., Usanbayev N.Kh. Izv. Vyssh. Uchebn. Zaved. Khim. Khim. Tekhnol. [Russ. J. Chem. \& Chem. Tech]. 2020. V. 63. N 12. P. 85-94 (in Russian).

20. Minakovsky A.F., Shatilo V.I. Bulletin of the National Academy of Sciences of Belarus, Series of chemical sciences. 2018. V. 54. N. 3. P. 376-384. ( in Belarus).

21. Nabiev M.N. Tashkent: FAN. 1976. P. 820. (in Uzbekistan).

22. Orlov D.S., Grishina L.A. Workshop on the chemistry of humus. M: Publishing house of Moscow. University. 1981. P. 272. (in Russian). 